\title{
Multiple lymphomatous polyposis of intestine as presentation of mantle cell lymphoma
}

\author{
Paloma Álvarez-Martínez ${ }^{1}$, María Pipa-Muñiz¹, Carlos Ordieres-Díaz¹, Iván Fernández-Vega², \\ María Antonia Palacio-Galán ${ }^{1}$, Pablo Granero-Castro ${ }^{3}$ and Adolfo Suárez-González ${ }^{1}$ \\ Departments of ${ }^{1}$ Gastroenterology and Hepatology, ${ }^{2}$ Pathology and ${ }^{3}$ General Surgery. Hospital Universitario \\ Central de Asturias. Oviedo, Spain
}

\section{CASE REPORT}

We report a case of a 78-year-old man previously diagnosed with colonic diverticular disease seen in a colonoscopy 4 years before. The patient presented lower gastrointestinal tract bleeding during the previous weeks without any other digestive symptom. Physical examination was normal. Laboratory data revealed hemoglobin concentration $11.9 \mathrm{~g} / \mathrm{dl}$ and reticulocytosis $145.6 \times 10^{3} \mu \mathrm{L}$. Colonoscopy showed colonic diverticulosis and multiple polypoid tumors $(<10 \mathrm{~mm})$ with submucosal aspect, hyperemia in the central zone and some of them bled easily on touch. Similar lesions, but bigger (12$15 \mathrm{~mm}$ ), were found by ileoscopy (Fig. 1) and multiple biopsies were taken. Computed tomographic scan did not reveal either pathologic lymph nodes or other disorders. Histologically, an atypical lymphoid proliferation in the submucosa was seen. The lymphoma cells were positive for CD20, CD 5, and cyclin D1 and high Ki-67 proliferative index (Fig. 2). A final diagnosis of mantle cell lymphoma (MCL) was made. Pathologic study of the bone marrow was normal and the bone marrow myelogram showed mature lymph nodes suggesting infiltration of non-Hodgkin lymphoma.

\section{DISCUSSION}

MCL is a relatively uncommon type of malignant B-cell non-Hodgkin lymphoma (6\%). The incidence is higher in elderly males and frequently presented with advanced-staged disease (1). Extranodal involvement is found in approxi-
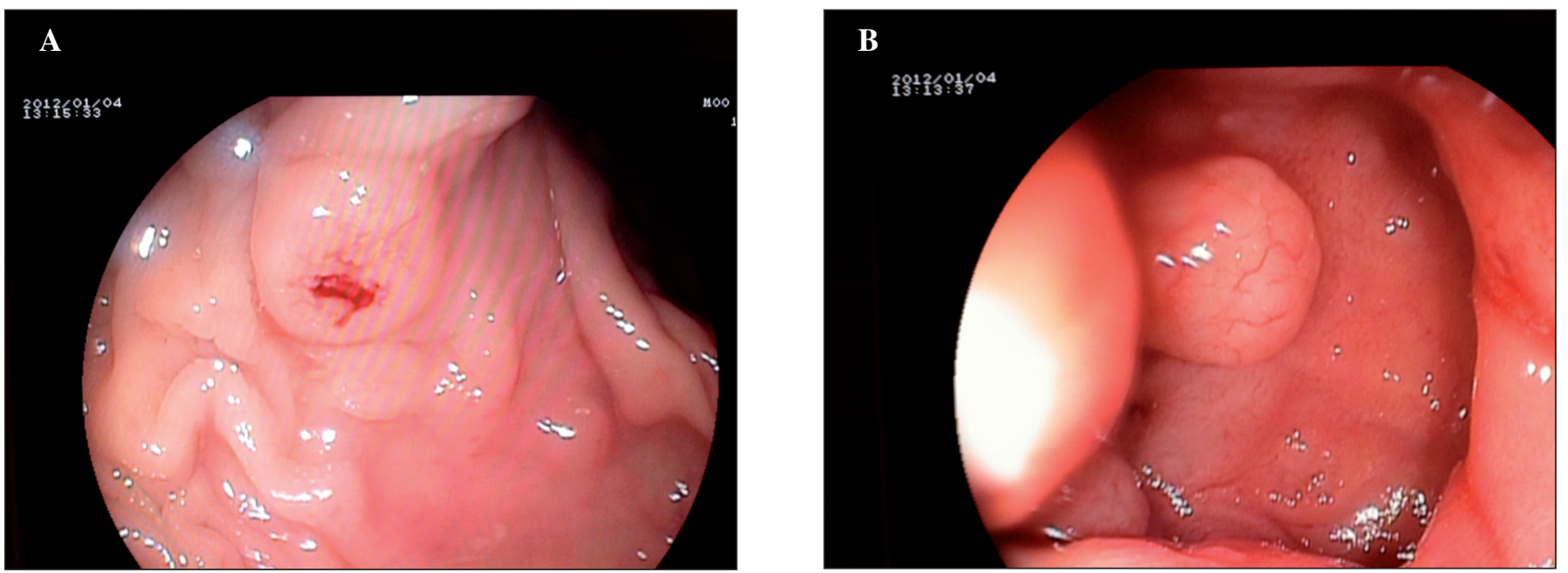

Fig. 1. A. Haemorrage in colonic polypoid lesion. B. Ileum mucosa with central hyperemic polypoid lesion. 

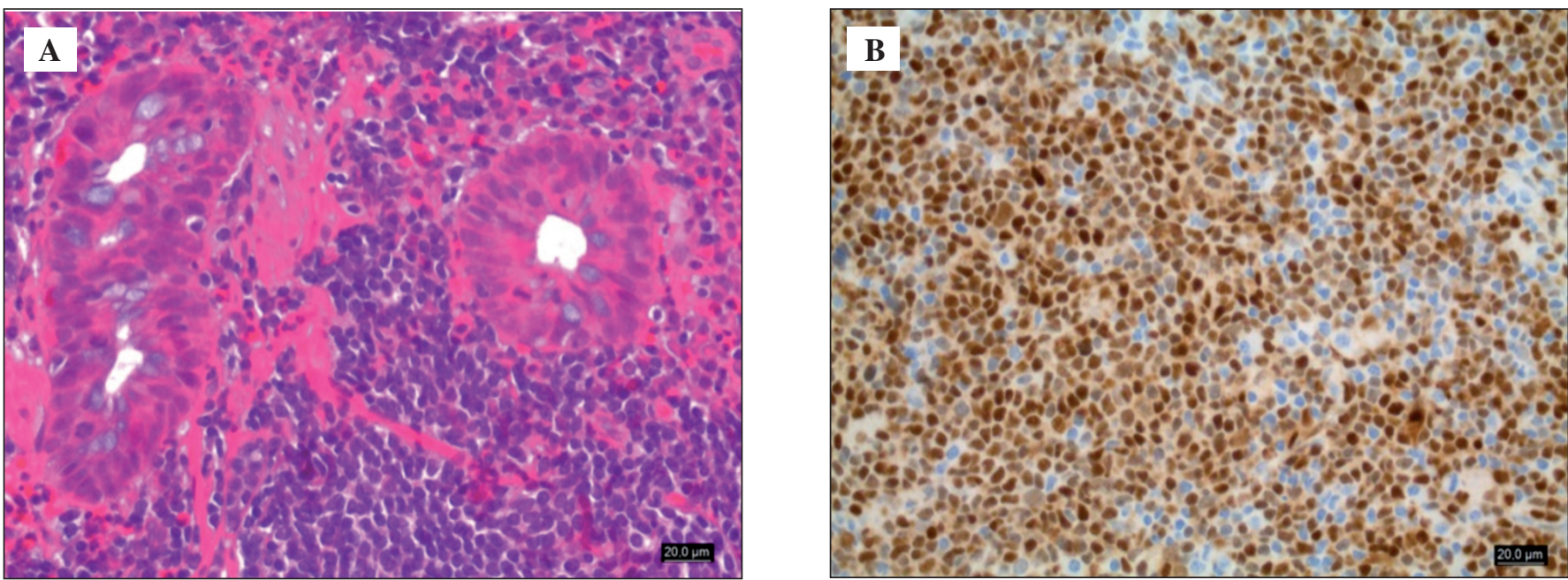

Fig. 2. A. Colon biopsy showing lymphoma cells (HE x 400). B. Immunohistochemical stain positive for cyclin D1 (x 400).

mately $90 \%$ of cases, including bone marrow, liver and gastrointestinal tract. In the intestine, it appears as a multiple lymphomatous polyposis. MCL is characterized by the chromosomal translocation $\mathrm{t}(11: 14)(\mathrm{q} 13$; $\mathrm{q} 32)$ and the overexpression of the cyclin D1 confirms the diagnosis (2). MCL is the least common of all the gastrointestinal lymphomas and it is considered incurable.

Although many of the treatments available today are shrouded in controversy, combined therapies (chemotherapy, immunotheraphy and proteasome inhibitors) can lead to long term progression-free survival more than 6 years after diagnosis (3).

\section{REFERENCES}

1. Witzg TE. Current treatment approaches for mantle-cell lymphoma. J Clin Oncol 2005;23:6409-14.

2. Lenz G, Dreyling M, Hiddemann W. Mantle cell lymphoma: established therapeutic options and future directions. Ann Hematol 2004;83:71-7.

3. Geisler CH, Kolstad A, Laurell A, Andersen NS, Pedersen LB, Jerkeman M,et al. Long-term progression-free survival of mantle cell lymphoma after intensive front-line immunochemotheraphy with in vivo-purged stem cell rescue: a non randomized phase 2 multicenter study by the Nordic Lymphoma Group. Blood 2008;112:2687-93. 